\title{
Un apéndice ornamental a Reyes en el ms. M1 de la Universidad Complutense de Madrid
}

\author{
M. J. DE AZCÁRRAGA* \\ Instituto de Filología - CSIC, Madrid
}

\section{INTRODUCCIÓN}

El manuscrito M1 de la Biblioteca de la Universidad Complutense de Madrid, precioso códice toledano del siglo XIII, es, desde antiguo, suficientemente conocido por los especialistas, porque fue uno de los manuscritos empleados por Alfonso de Zamora para la edición de la Políglota Complutense. En los últimos tiempos ha sido objeto de estudios generales y parciales, y en la actualidad el equipo de Biblia Hebrea del Instituto de Filología del CSIC está editando sus masoras ${ }^{1}$.

*azcarraga@filol.csic.es

1 Para la descripción, contenido y bibliografía de este manuscrito cf. F. J. DEL BARCO DEl BARCo, Catálogo de manuscritos hebreos de la Comunidad de Madrid. Volumen 1. Estudios introductorios por M. ${ }^{\mathrm{a}}$ T. ORTEGA MONASTERIO, M. ${ }^{\mathrm{a}} \mathrm{J}$. DE AZCÁRraga SERVERT y L. VEgas Montaner (Madrid 2003) págs. 109-112; cuando se publique este artículo ya se habrán publicado otros tres volúmenes sobre el M1: E. FERnándeZ TeJero, Las masoras del libro del Génesis. Códice MI de la Universidad Complutense de Madrid (Madrid 2004); M. J. DE AzCÁRRAGA SERVERT, Las masoras del libro de Levítico. Códice MI de la Universidad Complutense de Madrid (Madrid 2004); y las notas masoréticas de los Apéndices I, III y IV (cf. nota 5).

Sefarad 64 (2004) págs. 227-241

(c) CSIC

ISSN 037-0894 
Cuando este manuscrito llegó a la Universidad Complutense de Madrid, procedente de Alcalá de Henares ${ }^{2}$, presentaba algunas mutilaciones en su interior. Alguien, enemigo de la cultura y amigo de lo ajeno, había cortado con una afiladísima navaja las bellas letras iniciales de algunos libros. Por eso, siempre hemos pensado que los dos folios que se ven cortados de la misma manera al final de los Profetas Primeros tenían que contener algo de interés, por ejemplo, un apéndice masorético a la sección, similar a los otros tres que aparecen al final del Pentateuco, los Profetas Posteriores y los Escritos. Lo más probable es que nunca lo sepamos, pero sí sabemos que, de haber existido algo, ya no existía cuando a finales del siglo XIX Ch. D. Ginsburg estudia este manuscrito para su edición de la Biblia.

Ginsburg hace una descripción detallada del M1 en el volumen introductorio a esa edición y en ella se refiere a que hay cuatro apéndices. Respecto al segundo, que es el aquí nos interesa, dice:

Appendix II.- This supplement, which follows the Former Prophets, occupies column 3 of fol. 158a. It gives: The List of variations between the Easterns and Westerns in the book of Kings (... ${ }^{3}$

Un estudio detallado del folio mencionado, hecho con ayuda de Javier del Barco ${ }^{4}$, nos ha llevado a la conclusión de que Ginsburg no da cuenta más que de una de las cuatro listas que conforman este apéndice, que además es, en nuestra opinión, la última lista que se escribió.

Este apéndice difiere de los otros tres apéndices del códice ${ }^{5}$ en dos aspectos, formal y de contenido. El primero es que no está escrito en línea tirada, sino siguiendo un complicado dibujo (cf. fig.

2 M. ${ }^{a}$ T. ORtega Monasterio, «Las Bibliotecas y sus manuscritos hebreos», en F. J. DEL BARCO DEL BARCO, Catálogo, págs. 25-33.

3 CH. D. GinsBuRg, Introduction to the Massoretico-Critical Edition of the Hebrew Bible, with a Prolegomenon by H. M. ORLisnKy (New York 1966) pág. 773.

4 Para la descripción del manuscrito en su Catálogo, cf. nota 1.

5 E. Martín Contreras, Apéndices masoréticos. Códice MI de la Universidad Complutense de Madrid (Madrid 2004). E. Martín considera que este apéndice II es una simple masora ornamental y no un apéndice. 
1); el segundo es que su información se restringe a los dos libros de Reyes.

Tenemos, no obstante, que considerarlo como un apéndice y no como una masora, porque no tiene como lema una palabra concreta de la página en la que aparece, que es lo usual en el manuscrito, y por su contenido claramente general. Las cuatro listas identificadas contienen: los sědarîm o secciones litúrgicas, los pěseqîm, las palabras vocalizadas con patah pese a llevar 'atnah o estar en sôf pasûq, y las diferencias entre las Biblias orientales (Babilonia) y las occidentales (Israel), todo ello referido sólo a los dos libros de Reyes.

\section{LISTA DE SĔDARIM}

Al final de casi todos los libros del manuscrito se informa en un pequeño recuadro del número de versículos y de sědarîm que contiene. Lo mismo ocurre al final del segundo libro de los Reyes, pero en lugar de un pequeño recuadro hay un dibujo, flanqueado por las palabras nז, "sé fuerte y nos mostraremos fuertes» (2 Sam 10,12). En el interior del dibujo encontramos la información sobre el número de los versículos del libro, escrita en línea tirada, מספר פסוקיא דספר מלכים אלף וחמש מאות ושלשים ושלשה וסימן אגללך; y de sus sĕdarîm, וסדריו לה מסלה, así como del versículo que está en medio del libro de Reyes, considerando los dos libros como uno solo, וחציו ויקבץ מלך ישראל (1 Reg 22,6).

Las líneas que enmarcan esta información, rectas y curvas, forman un dibujo de fácil lectura, que contiene parte de la lista de los sĕdarîm de los libros de Reyes. Es decir, que es aquí, al final de la segunda columna, donde comienza este apéndice (cf. fig. 2).

Doy a continuación la transcripción de la lista :

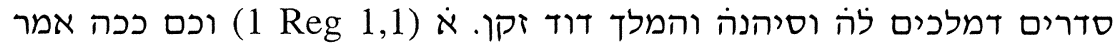

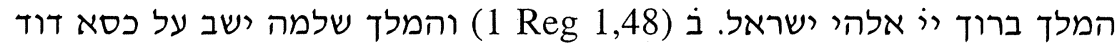

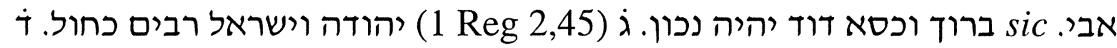

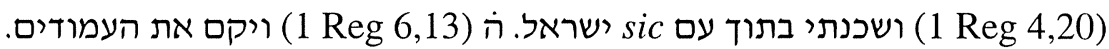

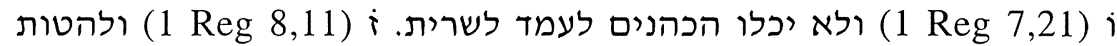

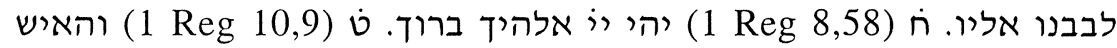




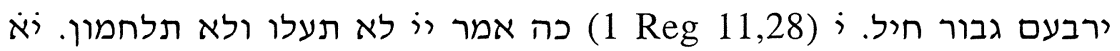

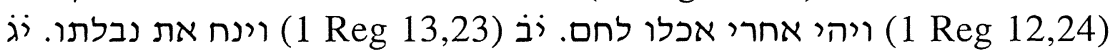

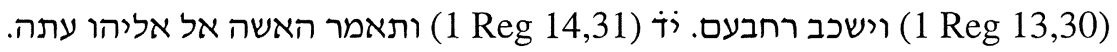

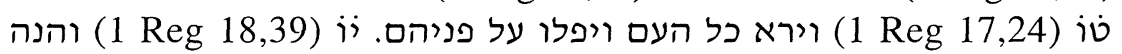
נביא אחד. יז (1Reg 20,13) ויהי דבר יi אל אליהו קדמ. יז (1Reg 21,17)

Hasta aquí llega el dibujo de la segunda columna. La lista se reanuda con el seder 19 en el interior del dibujo de la tercera columna.

וילך בכל דרך אסא אביו. יט (22,43 (1 Reg 2, ויראהו בני הנביאים אשר

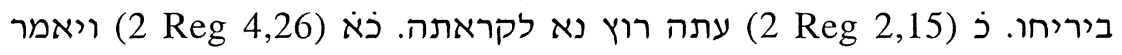

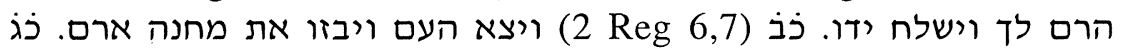

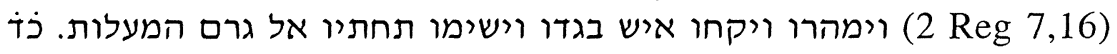

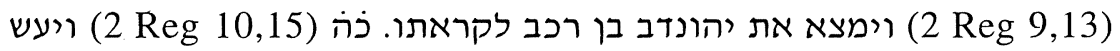

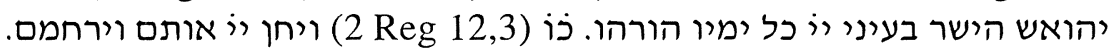

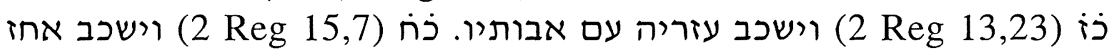

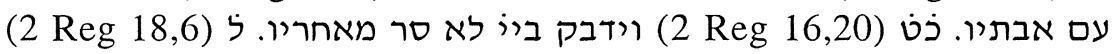

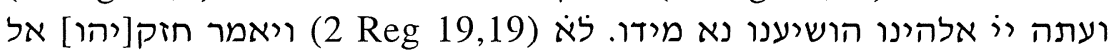

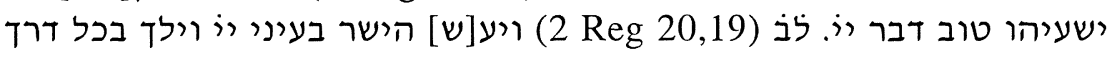

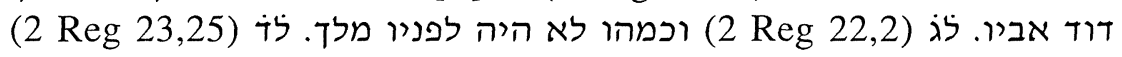

בן עשרים. לה (2 Reg 24,18).

Esta lista difiere de la de Ginsburg ${ }^{6}$ en cuatro pasajes: para el seder número 13 Ginsburg señala 1 Reg 15,8, y M1, que coincide con $\mathrm{BHS}^{7}$, 1 Reg 13,30; en el número 14, Ginsburg lista 1 Reg 16,15, frente a M1 que da el sîman de 1 Reg 14,31; el seder número 22 comienza según Ginsburg en 2 Reg 6,23, y según M1 y BHS en 2 Reg 6,7; por último, el seder 32 está en 2 Reg 20,8, según Ginsburg, y en 2 Reg 20,19 según M1. Este último caso parece una confusión del masoreta producida por el hecho de que ambos verויאמר sículos, el 8 y el 19, comienzan por las mismas palabras חזקיהו אל ישעיהו

6 CH. D. GinsBurg, The Massorah Compiled from Manuscripts..., With an Analytical Table of Contents and Lists of Identified Sources and Parallels by A. DOTAN, 4 vols. (New York 1975) II, págs. 331-332 § 83.

7 Biblia Hebraica Stuttgartensia... ediderunt K. ElLIGER et W. RudolPH. Textum Masoreticum curavit H. P. RÜGER. Masoram elaboravit G. E. WEIL (Stuttgart 1984). 
En el manuscrito los sĕdarîm aparecen señalados con un $\nabla$ inserto en un dibujo. En cuatro ocasiones las señales están en lugar distinto al que indica su lista. El seder 8 está junto a 1 Reg 8,57; el 13 está en 1 Reg 14,20; el 14 en 1 Reg 15,8, y el 22 en 2 Reg 6,23. El seder 35 no está marcado.

\section{LISTA DE P ESSEQÎM}

Si seguimos el orden del dibujo de la tercera columna, bastante más difícil de leer que el de la segunda ${ }^{8}$, debemos decir que a continuación de la lista de los sědarîm está la lista de los pěseqîm del libro de Reyes. Completa el dibujo la lista de palabras vocalizadas con patah, pese a llevar atnah o estar en sôf pasûq, sólo de Reyes. La última lista es, por lo tanto, la que rodea todo el dibujo, escrita una vez concluido éste, la de las diferencias entre orientales y occidentales, la que Ginsburg, en la Introducción a su Biblia ${ }^{9}$, consideraba como único contenido del apéndice.

Transcribo a continuación la segunda lista, la que contiene los pěseqîm de Reyes:

פסקתה דמלכין ויען בניהו בן יהוידע את המלך ויאמר | אמן (1, Reg (1,36)

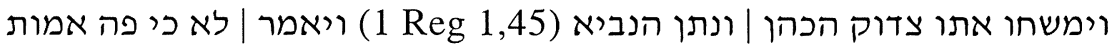

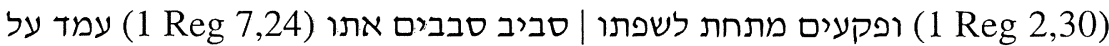

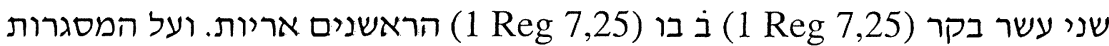

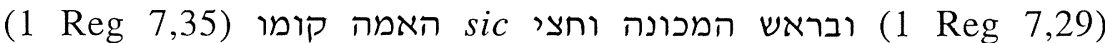
החג. ויעש שלמה (1) 8,65 (1) ולבנו אתן שבט אחד (1) Reg 11,36)

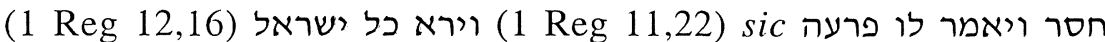

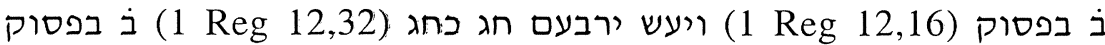

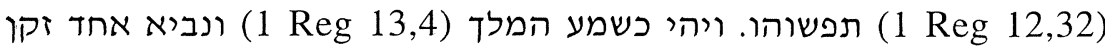

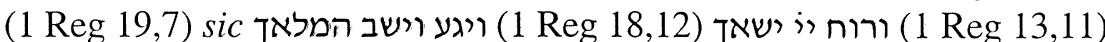

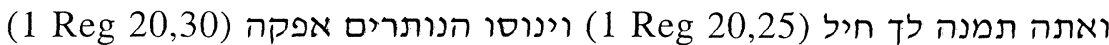
ויהי לי לגן דויאמר sic אחאב (1 Reg 21,2) ב 1 21,2)

8 La copia digitalizada del manuscrito M1, hecha con la subvención de la Comunidad Autónoma de Madrid, ayuda y facilita la lectura y la comprensión del texto.

9 Cf. nota 3. 


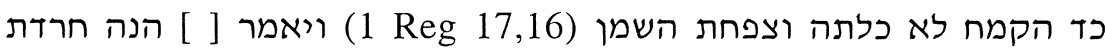
אלינו את כל החרדה (2Reg 4,13) ויאמר אל אל אביו ראשי (2Reg 4,19)

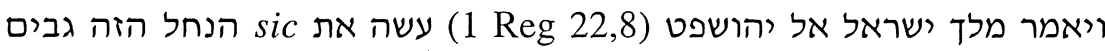

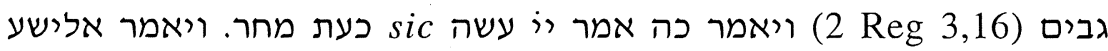

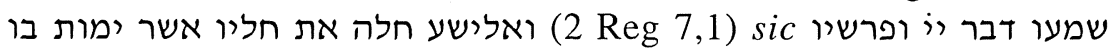

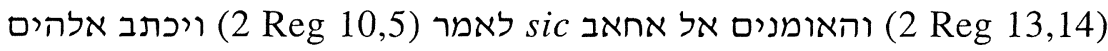

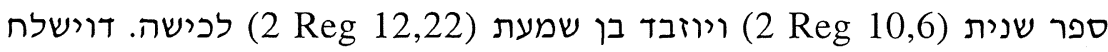

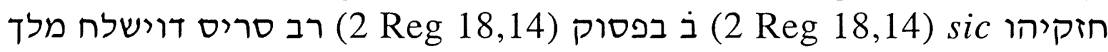

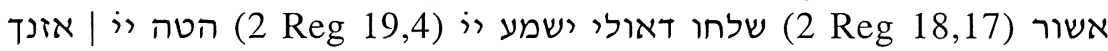

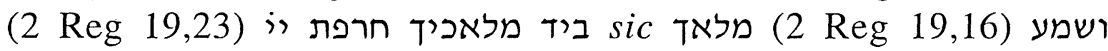

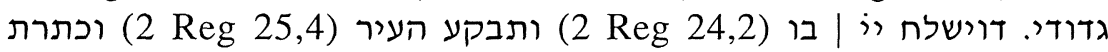

עליו נחשת (25,17)

Esta lista no es del todo coherente. Unas veces está señalado el paseq, otras no. Unas veces coincide con lo que vemos en el texto, otras no. Unas veces en el sîman aparecen las palabras donde está el paseq, otras no. Al principio del segundo libro vemos alterado el orden normal de la lista, quizá por necesidades del dibujo.

W. Wickes (W) dice que el número de pěseqîm en Reyes, según la lista del códice B19a de San Petersburgo (códice de Leningrado) es de 42,25 en 1 Reyes y 17 en 2 Reyes ${ }^{10}$. La lista que da M1 recoge, en efecto, 42 pasajes, como la lista de Wickes, pero hay alguna diferencia. Del primer libro de Reyes aparecen 25 pasajes, pero 1 Reg 17,16 (M1) está en lugar de 1 Reg 11,14 (W). Ninguno de los dos pasajes se encuentran en la lista de Ginsburg ${ }^{11}(\mathrm{G})$, que recoge sólo 24 pasajes de 1 Reyes, aunque como de 2 Reyes recoge 18 coincide en el cómputo total de 42 pěseqîm.

Norzi no hace comentario a 1 Reg 17,16 , pero respecto a 1 Reg 11,14 dice lo siguiente:

(...) en algunas ediciones hay paseq entre el Nombre y Satán (...), pero en los códices antiguos no está y tampoco en la lista de pěseqîm de Profetas ${ }^{12}$.

$10 \mathrm{~W}$. WiCKES, A Treatise on the Accentuation of the Twenty-one so-called Prose Books of the Old Testament (Oxford 1887) pág. 128.

1 CH. D. Ginsburg, The Massorah, I, págs. 648-649 § 208.

12 Y. S. de Norzi, Minhat Šay, según microfilme Add 27198 de la British Library, comentario a 1 Reg 11,14 . 
En los pasajes de 2 Reyes también hay alguna diferencia. Según Wickes, en 2 Reg 18,14 el paseq aparece tres veces; según M1, sólo aparece dos veces, y añade, en cambio, 2 Reg 18,17. M1 coincide con $\mathrm{G}$ en este pasaje, pero difiere en $2 \mathrm{Reg} 3,25$, que no aparece ni en $\mathrm{M} 1$ ni en $\mathrm{W}$.

En lo único que están de acuerdo las tres listas es en el cómputo total de 42 pěseqîm para Reyes (I y II).

\section{LISTA DE EXCEPCIONES CON PATAH}

En la tercera lista aparecen las palabras vocalizadas con patah, cuando deberían llevar qames por ir con 'atnah o estar en sôf pasûq. Se presenta siguiendo el orden de los versículos de los dos libros de Reyes, pero sin hacer distinción entre unos y otros casos. En todos ellos la palabra objeto de masora aparece delante del sîman.

La lista unificada es como sigue:

אלין פתחין בספרא באתנח בסוף פסוק וסימ [נהון] ולחיצון. ואת קרקע

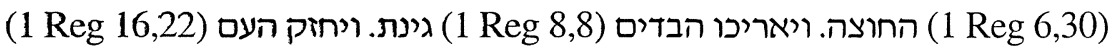

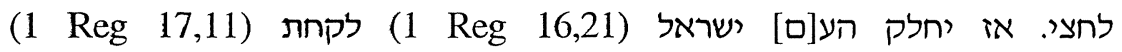

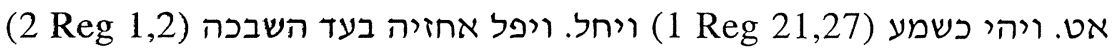

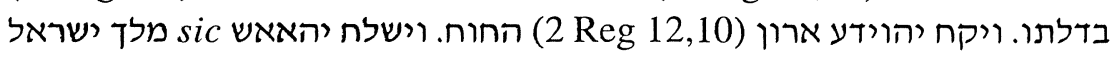

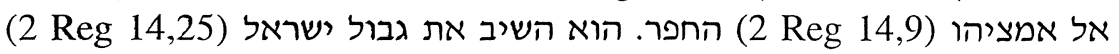

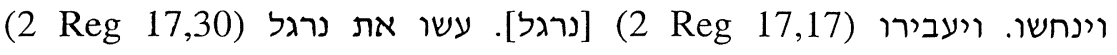

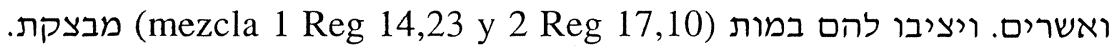
בן שמונה שנה יאשהו במלכו ושלשים ואחת שנה מלך בירושלם ושם אמו

.(2 Reg 22,1)

En la masora de Ginsburg esta masora se presenta en dos listas ${ }^{13}$. La primera de palabras con patah y atnah en el libro de Reyes recoge los pasajes siguientes: 1 Reg 8,8; 16,21.22; 17,11; 2 Reg 1,2; 12,10;15,16;17,17.30. La lista de M1 difiere en dos casos: falta ויך de 2 Reg 15,16, y añade ואשרים (1 Reg 14,23; 2 Reg 17,10), que en los dos pasajes en los que aparece va puntuada con 'atnah.

${ }^{13}$ CH. D. Ginsburg, The Massorah, II, pág. $301 \S 561$ y 562. 
En el texto del manuscrito se ha corregido la vocalización de גינת en 1 Reg 16,22 y de אט en 1 Reg 21,27, que en primera mano llevaban qames. En 1 Reg 17,11 la vocalización de masora. Y. S. de Norzi, cuyo trabajo persigue la corrección del texto bíblico en manuscritos y en ediciones, advierte: «El p con patah $y$ 'atnah» ${ }^{14}$, por lo que deducimos que la vocalización con qames. no es inusual.

En la lista de palabras con patah y sôf pasûq también hay dos diferencias: M1 omite ג גת de 1 Reg 2,39, y añade החוח de 1 Reg 14,9.

En ningún caso he encontrado junto al texto del manuscrito ninguna masora que aluda a estos dos fenómenos.

\section{LISTA DE VARIANTES ENTRE ORIENTALES Y OCCIDENTALES}

Una vez completado el dibujo, circunvalándolo, encontramos escrita, en su mayor parte en línea recta, la lista de variantes textuales entre textos orientales y occidentales, que transcribo a continuación:

חילוף ספרא שבין מערבאי ומדינחאי. למערבאי ואמתך ישינה מלא.

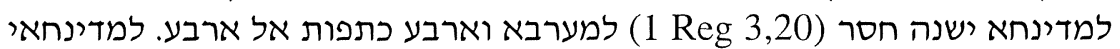

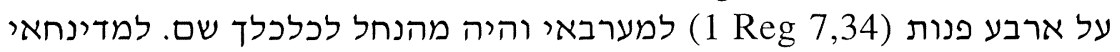

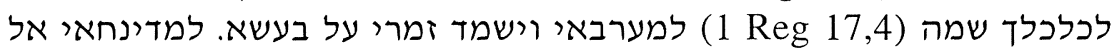

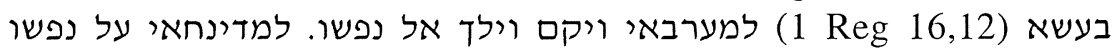
(1 Reg 19,3)

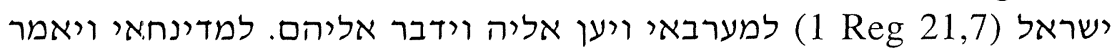

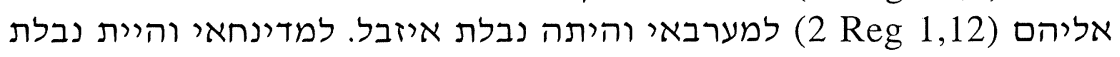

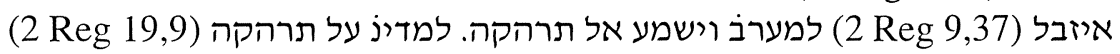

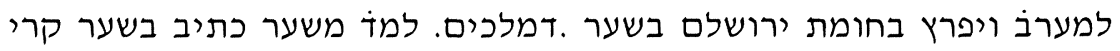

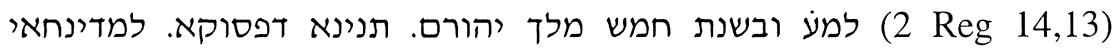

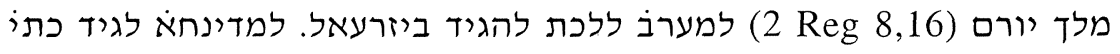

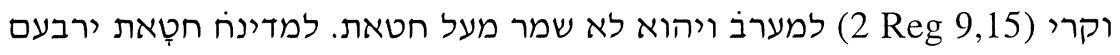

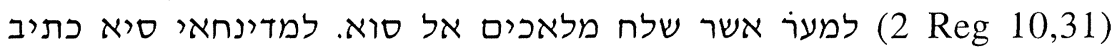
סוא קרי (2 Reg 17,4) למער אשר שלחי ויבא מלא אשור ומעוה ומחמת. למדינחאי סמאיב

14 Y. S. de Norzi, Minhat $\breve{S} a y$, comentario a 1 Reg 17,11 . 
ומעוא כתיב א (2Reg 17,24) למערבאי ומעוה ומחמת (2) 2 Reg 17,24)

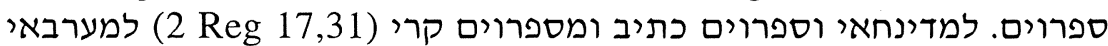

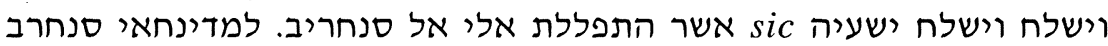

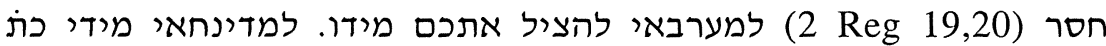

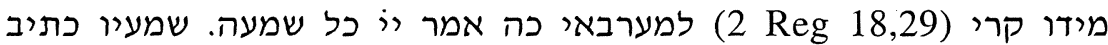

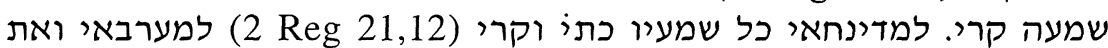
המזבחות עלית כת וקרי. למדי. למדינחאי עלות כתיב עלית קרי תמו פלוג למרי (23)

.(2 Reg 23,12)

Israel Yeivin nos dice acerca de estas diferencias:

A list copied at the end of some Bibles (as in L), or in separate treatises, gives about 250 differences between «Easterners» and «Westerners». This list is uniform in all sources, and gives variants only in the Prophets and Writings, not in the Torah. The variants listed are variants in the letters of the text, not in vocalization or accentuation. ${ }^{16}$

Sin embargo, es relativamente frecuente encontrar que en este tipo de variantes lo que en un escrito se atribuye a una lista, en otro se atribuye a la contraria. Por eso he comparado esta lista (M1) con las de Ginsburg ${ }^{17}(\mathrm{G})$ y Ben Hayyîm ${ }^{18}(\mathrm{BH})$ y he buscado los comentarios que hace Norzi en los casos dudosos.

Coinciden las tres listas en los casos de 1 Reg 17,4, 2 Reg 14,13; 17,31 y 23,12 .

También coinciden las tres listas entre sí, y con la masora parva de M1 ${ }^{19}$ los casos de 1 Reg 7,34; 19,3; 21,7; 2 Reg 1,12; 8,16; $9,15.37 ; 17,4 ; 18,29 ; 19,9$ y 21,12 .

${ }^{15}$ Repiten la entrada anterior y sólo ponen el lema que corresponde a la entrada siguiente.

16 I. YEIVIN, Introduction to the Tiberian Masorah. Translated and edited by E. J. REvELL, Masoretic Studies 5 (Missoula 1980) pág. 139

17 CH. D. Ginsburg, The Massorah, I, pág. $593 \S 625$.

18 Biblia Rabbinica: A Reprint of the 1525 Venice Edition. Edited by JACOB BEN HAYYIM IBN ADONIYA. Introduction by M. GOSHEN-GoTTSTEIN, 4 vols. (Jerusalem 1972) IV, pág. 245.

19 Las notas masoréticas que se refieren a estas variantes entre orientales y occidentales están escritas con tinta más tenue que las demás notas. Quizá fueron introducidas con posterioridad. 
En 1 Reg 3,20 las tres listas coinciden. Norzi también dice que según las listas:

ישינה se escribe pleno para los de Israel y defectivo para los de Babilonia, pero me resulta difícil aceptarlo, porque en todos nuestros códices está defectivo, y la masora dice: ישנה, 2 veces; el otro caso está en Cant $5,2^{20}$.

Así lo vemos escrito en el M1, ישנה, defectivo; su masora coincide con la de Norzi en afirmar que este caso es defectivo y difiere de ella al decir que el caso de Cant 5,2 es pleno: ذ غ מל וא חס אני ישינה מל ודין חס; M1 coincide con la masora de Weil ${ }^{21}$ en el enunciado y difiere al decir que éste es el caso defectivo.

En 1 Reg 16,12 el texto en M1 es אל בעשא, y su masora dice: 《למדj על בעשא", es decir, lo contrario de lo que dice en la lista de este apéndice, pero de acuerdo con las listas de G y BH. El comentario de Norzi aporta el testimonio de otros manuscritos que coinciden con M1 tanto en el texto, אל בעשא, como en la masora, «según los orientales עل ${ }^{22}$.

En 2 Reg 10,31 las tres listas difieren: BH omite este caso; G dice que los occidentales escriben מעל חטאת y los orientales מכל חטאת; y M1, tanto en esta lista como en la masora que hay junto al texto, atribuye la variante a la vocalización: «למדנחאי חטָאת ירבעם"), pero esto no puede ser correcto, pues como dice Yeivin, las variantes entre códices orientales y occidentales sólo afectan a las letras del texto ${ }^{23}$. En ese mismo sentido tendríamos que prescindir de los casos de ממנו//ממנו en 1 Reg 20,23 y 2 Reg 6,1, que sólo aparecen en la lista G, y de los que Ginsburg se hace eco en su Biblia.

En 2 Reg 17,24, acerca de ומעוא/ה, las tres listas coinciden en afirmar que según los occidentales se escribe con $n$ y según los orientales se escribe con $\mathcal{K}$. Encontramos lo contrario en el texto del M1, ומעוא, y en su masora, «למדj ומעוה כז ה".

20 Y. S. de Norzi, Minhat $\breve{S}$ Say, comentario a 1 Reg 3,20

${ }^{21}$ G. E. WEIL, Massorah Gedolah iuxta codicem Leningradensem B19a (Roma 1971) lista 3676.

22 Y. S. de Norzi, Minhat

23 Cf. supra, nota 12. 
Según el comentario de Norzi esto último es lo correcto:

En todos los códices está escrito ומעוא con y la masora dice al respecto: lêt escrito con $\boldsymbol{\kappa}$. Resulta difícil de comprender lo que veo en los hil.lûfim de la Biblia, donde está escrito que para los occidentales es con $\mathrm{n}$ y para los orientales con $\mathrm{x}^{24}$.

En 2 Reg 19,20 la lista de M1 difiere de G y BH. Para la primera, la variante está en que la palabra סנחריב esté con grafía plena (occidentales) o defectiva (orientales), mientras que para las otras dos listas la variante está en la partícula que precede a סל סנחריב

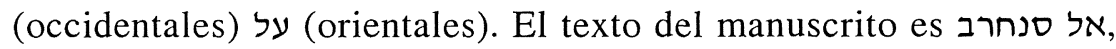
y, sorprendentemente, su masora dice: «למדj סנחרב חלסף. La Biblia de Ginsburg recoge ambas variantes, pero sólo menciona a orientales y occidentales en relación con אל על ערבויב En cuanto a son bastantes los códices y las ediciones que recogen una u otra grafía ${ }^{25}$.

La lista de M1 omite, quizá por falta de espacio, la variante del pasaje 2 Re 18,37: לו דברי, que sí encontramos en las listas G y BH. Acerca de ella nos dice Norzi:

Se encuentran textos en los que está escrito לו את דברי, que es la opinión de los orientales, pero según los occidentales se escribe y así lo he encontrado en los códices correctos, y en uno de ellos está escrito en el margen: «correcto sin $ת{ }^{26}$.

La lista masorética de Ginsburg es más larga que las de $\mathrm{BH}$ y M1. Aparecen en ella otras variantes relativas a la puntuación, que no parecen correctas ${ }^{27}$, y a la escritura de nombres propios con una sola palabra o con dos. A ellas se refiere Yeivin con estas palabras:

(...) the Masorah notes a few variants in addition to those in the list. These additional notes include a number of variants in method

${ }^{24}$ Y. S. de Norzi, Minhat $\underline{S}$ Šy, comentario a 2 Reg 17,24.

${ }_{25}$ CH. D. Ginsburg, The Earlier Prophets (London 1926) pág. 412.

26 Y. S. de Norzi, Minhat Šay, comentario a 2 Reg 18,37.

27 Cf. supra, pág. 9. 
-such as the fact that the Easterners read a group of letters as one word in many places where the Westerners read it as two, such as the names תובל־קין, בית־, etc. ${ }^{28}$

En el M1 todas las veces que aparece en el topónimo בית אל en el libro de Reyes está escrito con dos palabras, según la tradición occidental, pero en ningun caso se refleja que haya variantes al respecto, ni en una lista independiente ni con notas marginales de masora.

\section{CONCLUSIÓN}

El estudio detallado de la masora ornamental del folio $158 a$ del manuscrito M1 me permite completar y puntualizar la descripción que nos da Ginsburg de ese folio y que ha sido el punto de partida de este artículo.

Estoy de acuerdo con Ginsburg en calificar de apéndice este grupo de listas masoréticas. Ninguna de las cuatro listas depende de una palabra concreta de la página en la que se encuentra, como ocurre con las masoras. Son, como hemos visto, listas peculiares.

Estoy en desacuerdo con Ginsburg en el lugar donde empieza el apéndice, que él señala en la tercera columna y yo he demostrado que empieza en la segunda.

En cuanto al contenido del apéndice ya hemos visto que no contiene una única lista, según decía Ginsburg, sino que contiene cuatro listas.

28 I. YeIVIN, Introduction, pág. 140. 


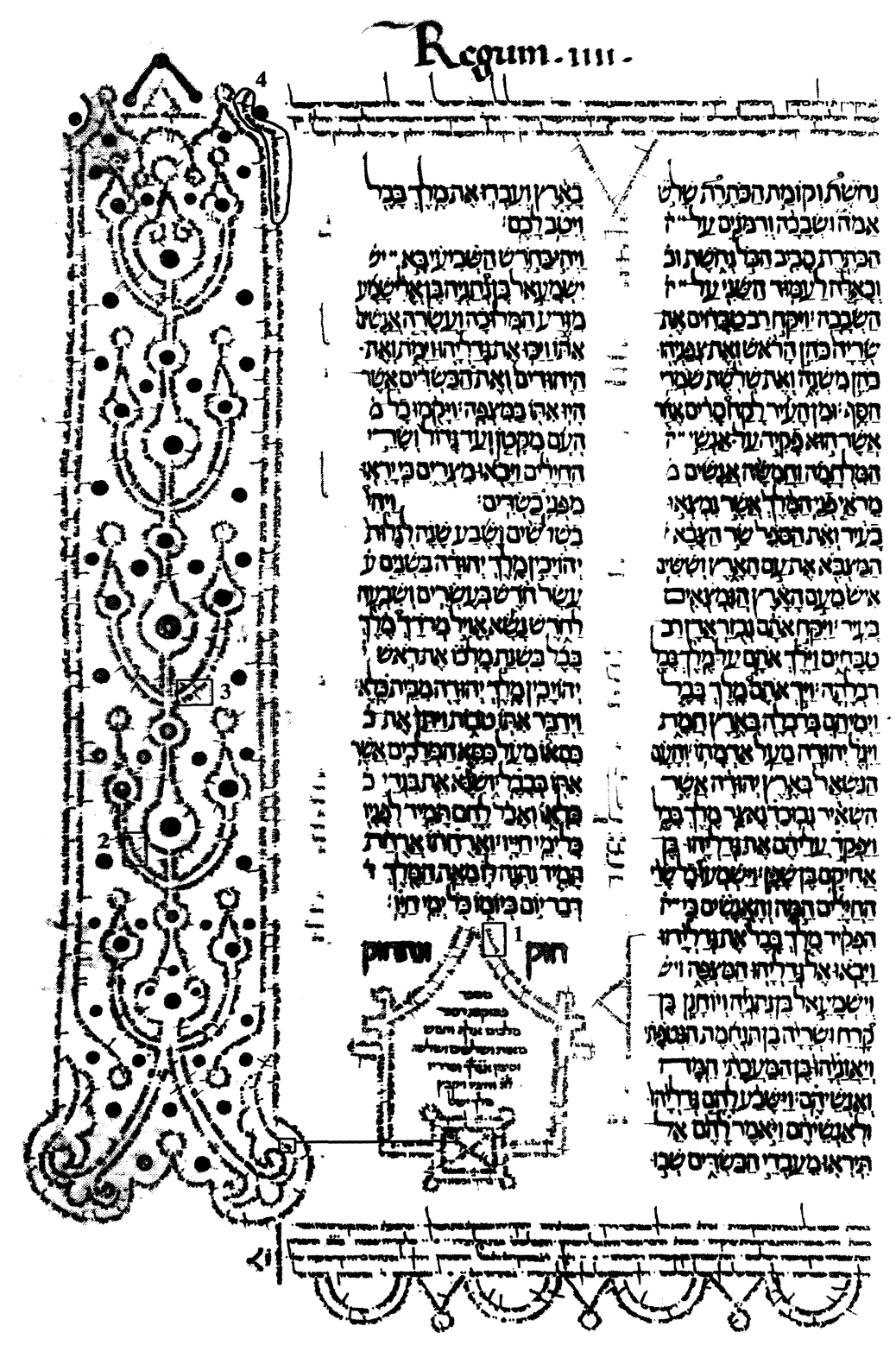

Fig. 1. 1: lista de sědarîm; 2: lista de pěseqîm; 3: lista de palabras con patah y 'atnah o sôf pasûq; 4: lista de diferencias entre orientales y occidentales. 


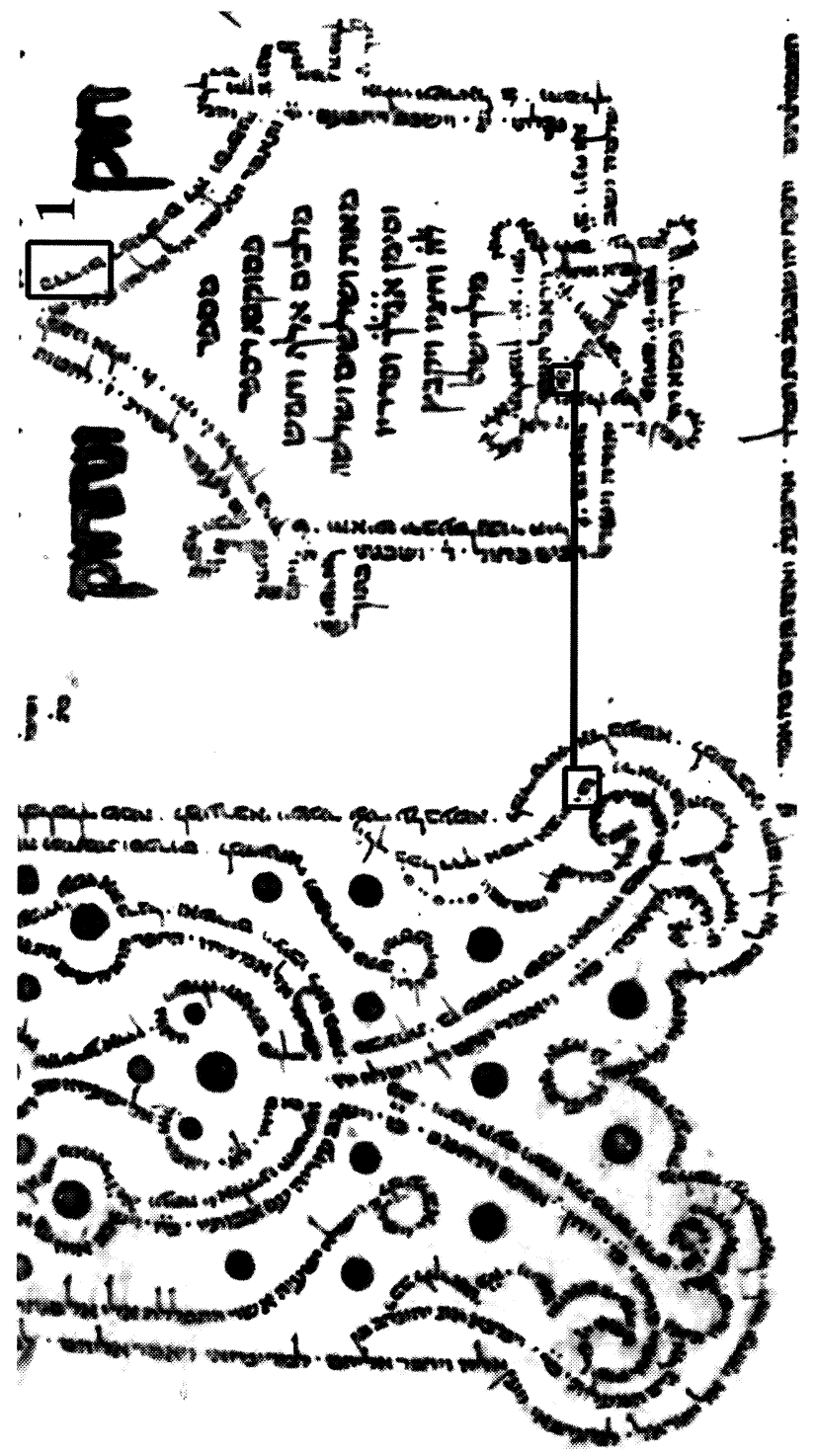

Fig. 2. Detalle ampliado del comienzo del Apéndice en la $2^{\mathrm{a}}$ columna y su continuación en la $3^{\mathrm{a}}$. 


\section{RESUMEN}

El estudio detallado de la masora ornamental del folio 158 a del manuscrito M1 me ha permitido corregir y puntualizar la descripción que hace de este folio $\mathrm{Ch}$. D. Ginsburg en la Introducción a su Biblia. Por una parte, estamos de acuerdo en que se trata de un apéndice masorético a los libros de Reyes, pero no lo estamos en lo que se refiere al sitio donde comienza, ni al contenido total del mismo. Ginsburg sólo describe una lista de las cuatro que contiene, la de las diferencias entre los textos orientales y occidentales; las otras tres son: sedarîm, paseqîm y palabras vocalizadas con patah, que constituyen una excepción por estar en pausa

Palabras Clave: Manuscrito bíblico, Libro de los Reyes, Masora, variantes.

\section{SUMMARY}

The analysis of the ornamental masorah of folio 158a of Manuscript M1 allows the author to correct and improve the description made by Ch. D. Ginsburg in his introduction to the Bible. The author indeed agrees on the identification of the text as a masoretic appendix to the books of Kings. However, the beginning and the contents of the manuscript must be revised. Ginsburg describes only one of the four lists of the appendix, namely the one dealing with the differences between Eastern and Western recensions; the other three lists are the following: sedarim, peseqim, and words vocalized with patah, which are exceptional because they are pausal forms.

KEYWORDS: Biblical manuscript, Book of Kings, Masorah, variants. 